\title{
Pusat Ilmu Pengetahuan Sebagai Wahana Rekreasi Edukatif Dengan Pendekatan Arsitektur Metafora Di Surakarta
}

\author{
Clara Afiliati Pritania, Agus Heru Purnomo, Leny Pramesti \\ Program Studi Arsitektur \\ Universitas Sebelas Maret Surakarta \\ Email : claraafiliati@hotmail.com
}

\begin{abstract}
Science Center's planning and designing in Surakarta, motivated by the rapid development of science and technology, the need a place for information and education about science and technology to wider community, the lack of recreation and education facilities about science and technology in Surakarta, and also one of the Surakarta government vision and mission to increase human resources through science and technology. The purpose are to get a building design that can accommodate either recreation and education activities about science and technology, and also the building form which can express the dynamic motion development of science and technology. The issue is how to interpret the dynamic motion of science and technology to the design itself. The methods using architecture metaphor methods. The results are Science Center which applying architecture metaphor intangible (abstract) through building circulation, space system, and the building form.
\end{abstract}

Keywords: Architecture, Architecture Metaphor, Exhibition Center, Metaphor Intangible, Science Center, Science and Technology.

\section{PENDAHULUAN}

Ilmu Pengetahuan dan Teknologi (IPTEK) yang berkembang dengan pesat tidak semuanya dapat diikuti oleh masyarakat, sehingga dibutuhkan suatu wadah yang menjadikan IPTEK diterima dan diperkenalkan secara luas dengan cara yang menyenangkan. Pusat Ilmu Pengetahuan (science center) adalah salah satu fasilitas pembelajaran informal yang menyediakan pengetahuan mengenai IPTEK yang memiliki jangkauan secara luas dan dimanfaatkan pula dalam pendidikan formal (Panda \& Bikash R.M, 2010). Menurut Ramey Gasser, Rennie \& McClafferty (dalam Rahm, 2004) secara khas Pusat Ilmu Pengetahuan menawarkan interaksi langsung antara pengunjung dengan koleksi, tidak adanya rute khusus untuk menikmati koleksi, adanya pengalaman nonverbal, dan koleksi visual untuk menyampaikan konsep ilmu pengetahuan

Pusat Ilmu Pengetahuan yang menawarkan interaksi langsung dengan koleksi peraga dapat bermanfaat bagi semua kalangan masyarakat. Menururt Salmi (dalam Persson, 2014) pelajar sekolah dasar adalah kelompok yang paling berpengaruh positif (dalam Persson, 2014). Namun tidak menutup kemungkinan bagi orang dewasa untuk ikut belajar dan melakukan eksperimen, hal ini dibuktikan oleh Medved dan Oakley (dalam Persson, 2014) yaitu $1 / 3$ orang dewasa dari hasil wawancara mampu menghubungkan percobaan koleksi peraga terhadap kejadian sehari-hari.

Embrio Solo Science Center di kawasan Solo Technopark kota Surakarta, merupakan salah satu perwujudan visi misi Kota Surakarta dalam meningkatkan sumber daya manusia melalui bidang IPTEK tertuang dalam Peraturan Daerah Kota Surakarta no.10, tahun 2001. Namun penempatannya masih meminjam tempat di teaching factory dan memiliki fasilitas terbatas, sehingga kebutuhan wadah akan Pusat Ilmu Pengetahuan semakin mendesak. Pusat Ilmu Pengetahuan memberikan fungsi hiburan dan mendidik mengenai IPTEK kepada pengunjung, sehingga masyarakat dapat memanfaatkan waktu luang dengan nuansa edukatif.

Pusat Ilmu Pengetahuan merupakan wahana rekreasi edukatif untuk mengenal dan mempelajari IPTEK dengan menyenangkan. Fasilitas yang direncanakan harus dapat menarik perhatian masyarakat dan dapat mengekspresikan gerak dinamis 
perkembangan IPTEK. Arsitektur Metafora yang diaplikasikan secara abstrak dinilai sesuai untuk memperlihatkan fungsi dan karakteristik gerak dinamis IPTEK yang terus berkembang dan berinovasi.

Pusat Ilmu Pengetahuan yang direncanakan diharapkan mampu mewadahi kegiatan rekreasi dan edukasi mengenai IPTEK, serta bentuk bangunan yang dapat mengekspresikan gerak dinamis IPTEK yang terus berkembang dan berinovasi.

\section{METODE}

Berdasarkan konsep perencanaan dan perancangan, Pusat Ilmu Pengetahuan yang direncanakan menerapkan Arsitektur Metafora Abstrak yang memenuhi kebutuhan dan kenyamanan pengunjung dengan mengaplikasikan metafora gerak dinamis IPTEK yang tak beraturan, fleksibel atau menyesuaikan keadaan, dan terus berproses.Metafora diaplikasikan pada desain sirkulasi, tata ruang, dan bentuk bangunan.

Tapak yang berlokasi di kawasan, mennyebabkan sirkulasi menjadi aspek penting untuk dipertimbangkan. Letak jalan masuk dan keluar serta letak bangunan yang sudah ada menjadi pertimbangan untuk menghindari terjadinya sirkulasi silang antar pengunjung dan kegiatan servis. Sirkulasi dalam tapak dan bangunan mempertimbangkan metafora yang fleksibel terhadap keadaan, sehingga disesuaikan dengan kebutuhan pengguna kegiatan. Pengolahan kontur tapak menggunakan metafora tak beraturan, sehingga kontur tapak tetap dipertahankan.

Penataan zona utama bangunan yang terdiri dari ruang pamer tidak tetap, ruang pamer tetap, kids field, science theater, dan ruang seminar mengadopsi alur skema penelitian yang dinamis. Ruang pamer tetap yang terdiri dari kelompok wahana mengadopsi metafora yang terus berproses, sehingga disesuaikan dengan tema kelompok wahana masing-masing dan dapat dipindahkan.

Bentuk bangunan Pusat Ilmu Pengetahuan mengadopsi bentuk atom, unsur terpenting dalam bidang IPTEK, dengan memberikan kesan dinamis. Transformasi bentuk dinamis memberikan konsekuensi pada struktur bangunan yang mampu menahan beban bangunan dan mempertahankan bentuk massa.

\section{ANALISIS}

\subsection{Analisis Peruangan}

Kebutuhan ruang didapat dari pertimbangan kegiatan yang dilakukan oleh pelaku kegiatan di dalam Pusat Ilmu Pengetahuan.

Tabel 1.Kebutuhan Ruang

\begin{tabular}{|c|c|c|}
\hline $\begin{array}{c}\text { Pelaku } \\
\text { Kegiatan }\end{array}$ & Jenis Kegiatan & $\begin{array}{c}\text { Kebutuhan } \\
\text { Ruang }\end{array}$ \\
\hline Pengunjung & $\begin{array}{l}\text { - Bilas/mandi } \\
\text { - Melihat dan } \\
\text { mencoba } \\
\text { koleksi peraga } \\
\text { anak } \\
\text { - Menonton } \\
\text { Film sains } \\
\text { - Seminar/ } \\
\text { diskusi } \\
\text { - Lomba/acara } \\
\text { - Membaca } \\
\text { buku } \\
\text { - Metabolisme } \\
\text { - Ibadah } \\
\text { - Istirahat } \\
\text { - Makan } \\
\text { - Membeli } \\
\text { souvenir }\end{array}$ & $\begin{array}{l}\text { Main } \\
\text { Entrance } \\
\text { Tempat } \\
\text { Parkir } \\
\text { Loket Tiket } \\
\text { Lobby/Front } \\
\text { Office } \\
\text { Permanent } \\
\text { exhibition } \\
\text { area, Non- } \\
\text { permanent } \\
\text { exhibition } \\
\text { area, dan } \\
\text { outdoor } \\
\text { Ruang bilas } \\
\text { Kids Field }\end{array}$ \\
\hline Pengelola & $\begin{array}{l}\text { - Datang-pergi } \\
\text { - Parkir } \\
\text { - Bekerja }\end{array}$ & $\begin{array}{l}\text { Main } \\
\text { Entrance } \\
\text { Tempat parkir } \\
\text { pengelola } \\
\text { Kantor setiap } \\
\text { di }\end{array}$ \\
\hline
\end{tabular}




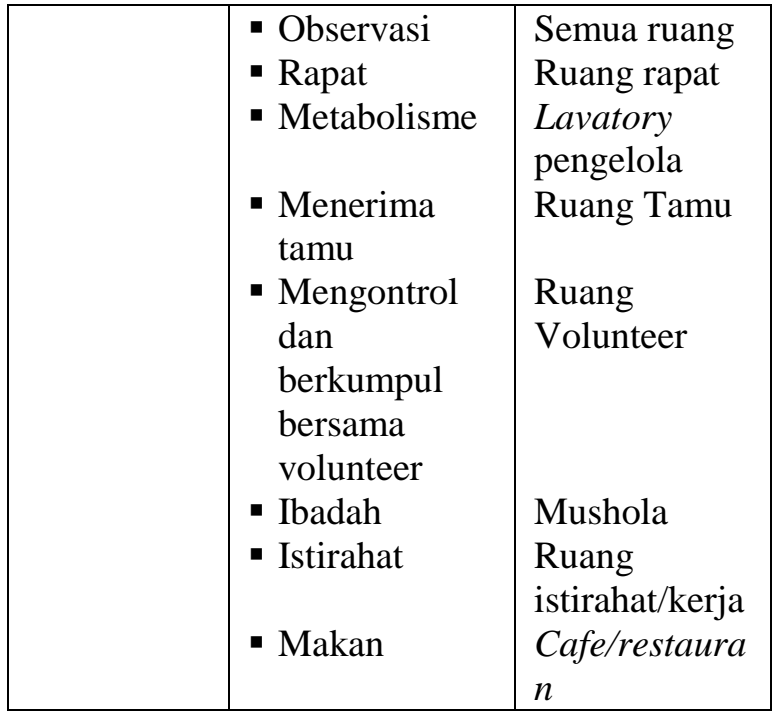

Pada Tabel 1 terlihat kebutuhan peruangan yang dibutuhkan untuk mewadahi kegiatan pengunjung. Sedangkan pada Tabel 2 terlihat ruang-ruang kebutuhan untuk mewadahi kegiatan pengelola Pusat Ilmu Pengetahuan.

\subsection{Analisis Tapak}

\subsubsection{Analisis Usulan Perencanaan Kawasan}

Pemilihan tapak didasarkan pada beberapa rencana pemerintah

1. Tujuan: mengoptimalkan penggunaan kawasan sebagai tempat perkembangan IPTEK di Surakarta

2. Dasar pertimbangan: Pengupayaan lahan terhadap obyek-obyek sekitar, argumen dan kesepakatan yang bertanggungjawab, dan pertimbangan nilai kompatibilitas bangunan terhadap dampak lingkungan sekitar.

3. Hasil:

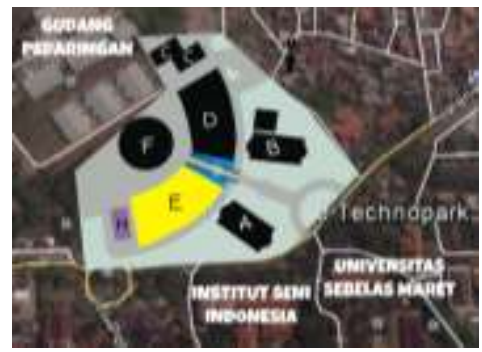

Gambar 1. Kawasan Eksisting Solo Technopark

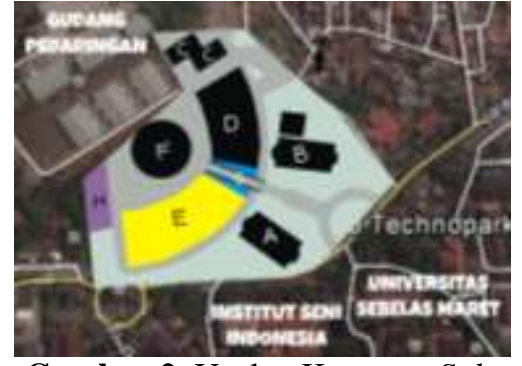

Gambar 2. Usulan Kawasan Solo Technopark

Pada Gambar 1 merupakan kawasan eksisting dari perencanaan pemerintah kota Surakarta, dengan perencanaan tapak Pusat Ilmu Pengetahuan pada bagian (E). Sedangkan pada Gambar 2 merupakan usulan kawasan dengan keterangan sebagai berikut :

1. Pengolahan main entrance dengan pemberian sculpture atau spanduk

2. Penyediaan kantong parkir mobil pada bangunan Admin Office \& Observation Tower $(\mathrm{F})$

3. Relokasi Industry Cluster (C) ke Barat Laut kawasan

4. Penyediaan kantong parkir bus kawasan $(\mathrm{H})$

5. Pembenahan dan perawatan bangunan Teaching Factory (A) dan pengelolaan tata landscape kawasan

6. Pengadaan jembatan integrasi antara tapak Pusat Ilmu Pengetahuan (E) dengan Solo Trade Center (D)

7. Pelebaran tapak Pusat Ilmu Pengetahuan (E) dengan memanfaatkan tapak relokasi Industry Cluster (C)

\subsubsection{Analisis Tapak}

Pemilihan tapak didasarkan pada beberapa rencana pemerintah

1. Tujuan: Mendapatkan lokasi yang sesuai dengan fungsi bangunan

2. Dasar pertimbangan: berdasarkan RTRW Kota Surakarta Tahun 2011-2031, peta kawasan strategis Kota Surakarta, dan rencana tapak oleh Pemerintah Surakarta

3. Hasil: Tapak terpilih berada di kawasan Solo Technopark. Tapak memiliki luas $\pm 6855 \mathrm{~m}^{2}$ dengan keliling $\pm 380,29 \mathrm{~m}^{2}$. Batas-batas tapak dapat terlihat pada Gambar 3. :

Timur Laut : Jembatan (G) dan Solo Trade Center (D)

Teggara : Jalan dan Teaching Factory (A) 
Barat Daya : Jalan dan Kantong Parkit Bus (H)

Barat Laut : Jalan dan Admin Office \& Observation Tower $(\mathrm{F})$

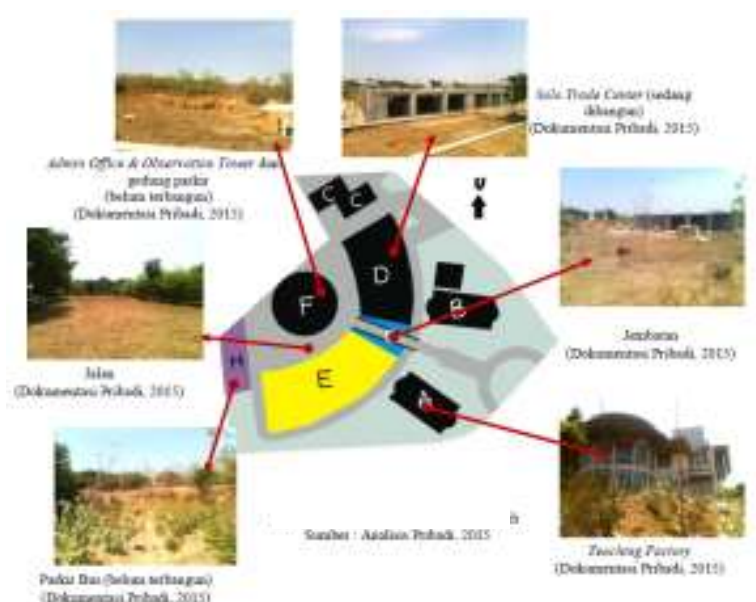

Gambar 3. Tapak dan Batas-Batas Tapak

\subsubsection{Analisis Pencapaian}

Pencapaian menuju tapak relatif mudah karena kawasan berada di pinggir jalan besar $\mathrm{Ki}$ Hajar Dewantara $( \pm 7 \mathrm{~m})$ dan jalan baru $( \pm 5 \mathrm{~m})$. Lokasi tapak dalam kawasan relatif mudah karena dekat dengan jembatan kawasan dan Admin Office \& Observation Tower sebagai poin utama kawasan.

1. Tujuan: Menentukan main entrane, dan side entrance tapak

2. Dasar Pertimbangan: Metafora dinamis yang menyesuaikan keadaan, kemudahan pencapaian, letak main entrance dan side entrance kawasan, arus kendaraan dan keamanan, pengelompokkan kegiatan

3. Hasil:

Main Entrance (ME)

Berada di bagian Barat Laut dengan akses masuk dan keluar dipisah, supaya tidak terjadi sirkulasi silang. ME digunakan untuk pengunjung dan pengelola. Akses keluar dari basement, seperti pada Gambar 4, juga berada di bagian belakang tapak, untuk menghindari menumpuknya kendaraan saat keadaan darurat

Side Entrance (SE)

Berada di bagian tenggara untuk kegiatan servis. Akses masuk dan keluar SE tapak dipisahkan supaya kendaraan barang dapat langsung keluar menuju SE kawasan.

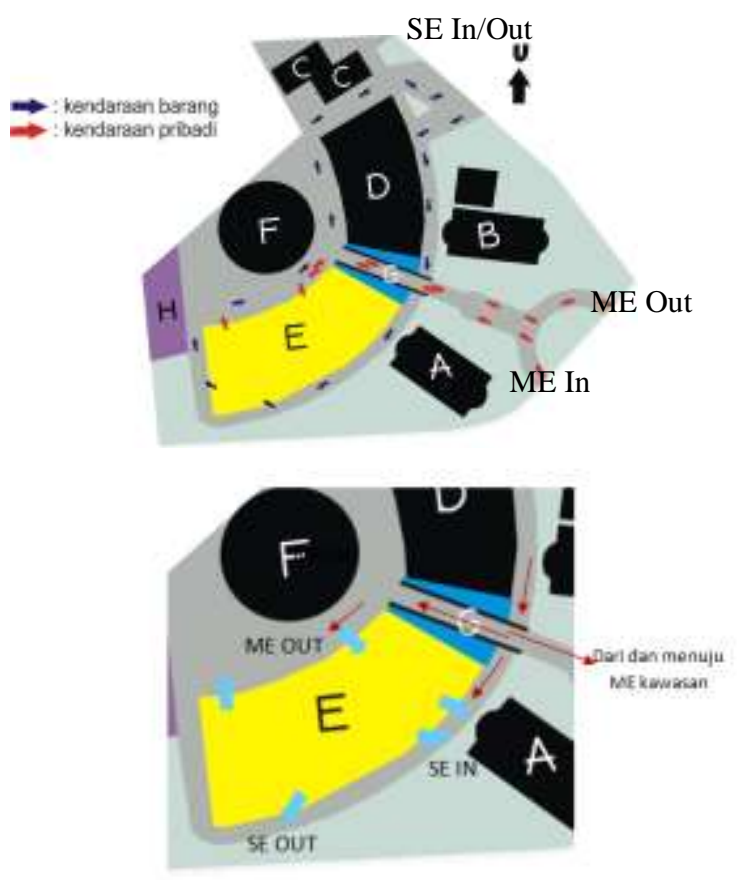

Gambar 4. Pola Pencapaian Kawasan dan Tapak

\subsubsection{Analisis Pemintakatan}

Pemintakatan dijadikan sebagai acuan dalam penataan peruangan dengan tetap memperhatikan beberapa pertimbangan.

1. Tujuan: Menentukan pemintakatan pada tapak

2. Dasar pertimbangan: analisis peruangan, kemudahan pencapaian, view dan orientasi, kebisingan, serta klimatologis

3. Hasil:

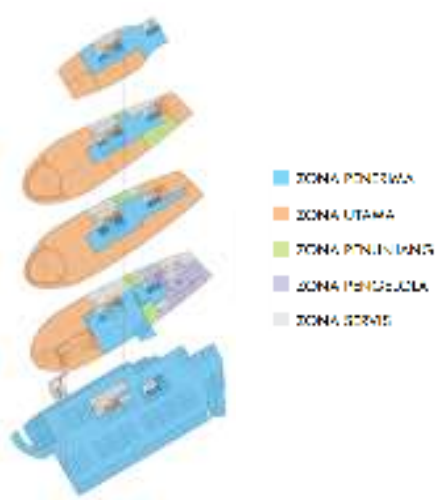

Gambar 5. Pemintakatakan pada Massa Bangunan

Pada Gambar 5 pemintakatan terbagi menjadi lima bagian yatu zona penerima, zona utama, 
zona pendukung, zona pengelola, dan zona servis.

\subsection{Analisis Bentuk dan Tatanan}

\subsubsection{Analisis Elevasi Bangunan}

1. Tujuan : menentukan ketinggian elevasi bangunan pada lantai dasar

2. Dasar pertimbangan : kontur tapak dan metafora IPTEK tak beraturan

3. Hasil : mempertahankan kontur pada lantai satu seperti terlihat pada Gambar 6, dengan mengadopsi proses perkembangan IPTEK tak beraturan yang mengalami keberhasilan (naik) dan kegagalan (turun).

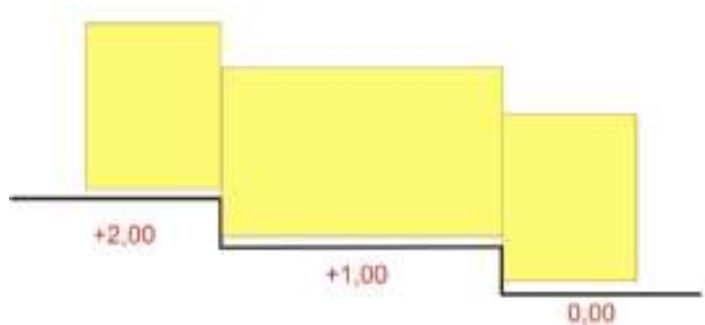

Gambar 6. Elevasi Bangunan pada Lantai Satu

\subsubsection{Analisis Bentuk Bangunan}

1. Tujuan : Menentukan bentuk bangunan yang mengekspresikan gerak dinamis IPTEK dan dapat menarik pengunjung

2. Dasar pertimbangan : bentuk atom yang menjadi dasar bentuk bangunan, respon bangunan terhadap analisis tapak dengan pertimbangan metafora gerak dinamis

3. Hasil :

Bentuk bangunan diperoleh dari struktur atom yang terdiri dari inti atom dan lintasan atom. Elektron pada atom yang mengeliling inti dan menghasilkan lintasan yang tak beraturan mempresentasikan ilmu pengetahuan yang terus bergerak secara dinamis. Inti atom yang berada di tengah mempresentasikan Pusat Ilmu Pengetahuan yang direncanakan sebagai satu wadah pusat kegiatan pembelajaran IPTEK bagi masyarakat di Kota Surakarta (Gambar 7a.).

Selubung bangunan yang mewadahi kegiatan inti Pusat Ilmu Pengetahuan diibaratkan elektron yang mengelilingi proton pada inti atom. Kulit bangunan mengambil bentuk lintasan elektron pada atom yang mengelilingi proton, kemudian ditransformasikan menjadi bentuk yang memberi kesan dinamis pada tampilan bangunan (Gambar 7b.)

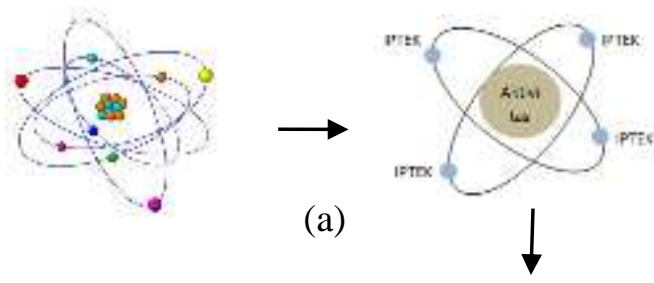

Selubung bangunan dibaratkan sebagai elektron yang mengelling inti atom

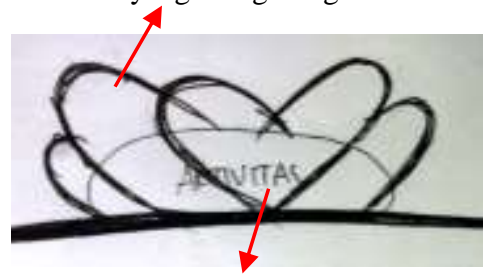

Pusat aktivitas di science centre diibaratkan sebagai inti atom.

Bentuk selubung bangunan yang diambil dari lintasan elektron ditransformasikan menjadi bentuk yang memberikan kesan yang lebih

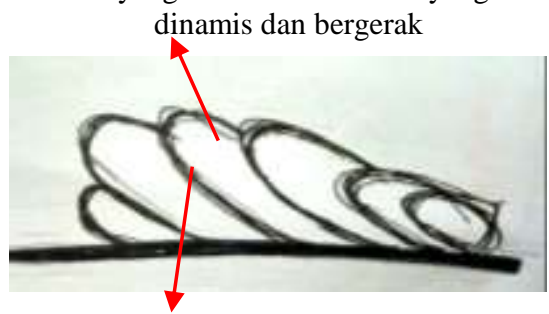

Diameter yang berbeda mengadopsi dari bentuk lintasan elektron yang memiliki beragam diameter

(b)

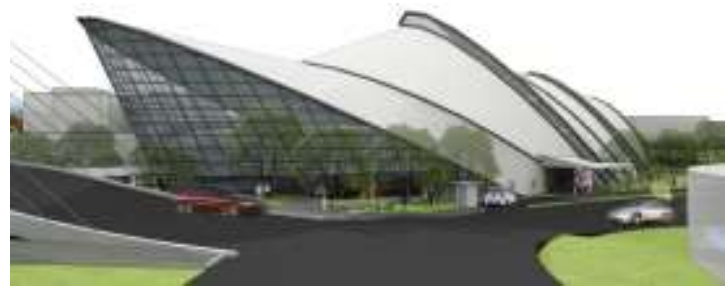

Gambar 7. Gubahan Massa

Pengolahan landscape pada tapak mengadaptasi bentuk lintasan elektron yang melengkung dan berpusat pada inti atom. Pada Gambar 8 lengkung yang digunakan adalah 
geometri garis tak beraturan yang menggambarkan gerak elektron dinamis. Pengaplikasiannya dapat berupa perbedaan perkerasan dengan tanah, pemberian peneduh, pemberian tempat istirahat, maupun kenaikan elevasi tanah. Pemberian elemen-elemen tersebut secara psikis dan visual seperti dinding di dalam bangunan, karena adanya batasan dalam visual dan gerak.

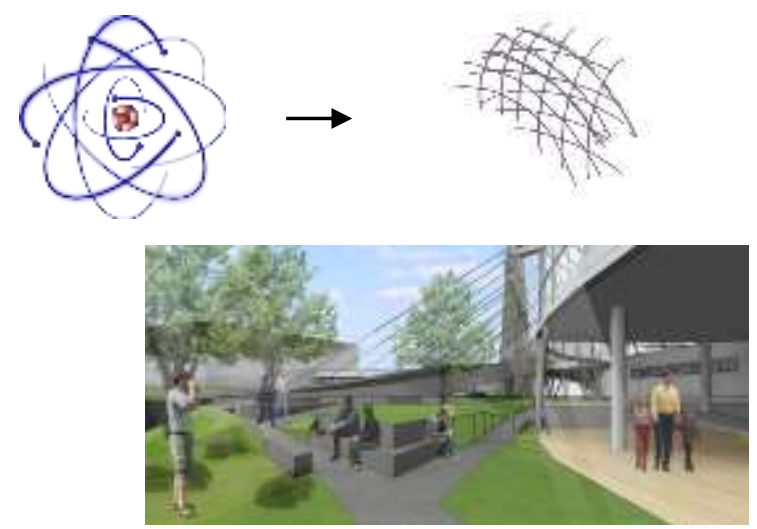

Gambar 8. Pengolahan Landscape

\subsubsection{Analisis Sirkulasi Zona Utama}

1. Tujuan: mendapatkan penataan ruang pada zona utama

2. Dasar pertimbangan : metafora skema penilitian, kebutuhan ruang, dan besaran ruang

3. Hasil : zona utama berfungsi sebagai penyampai informasi, terdiri dari ruang pamer (exhibition permanent, non permanent, dan kids field), science theater, perpustakaan, dan ruang seminar. Sirkulasi dan penataan ruang pada zona ini mengadopsi alur skema penelitian, dengan alur pengamatan, analisa data, dan hasil akhir.

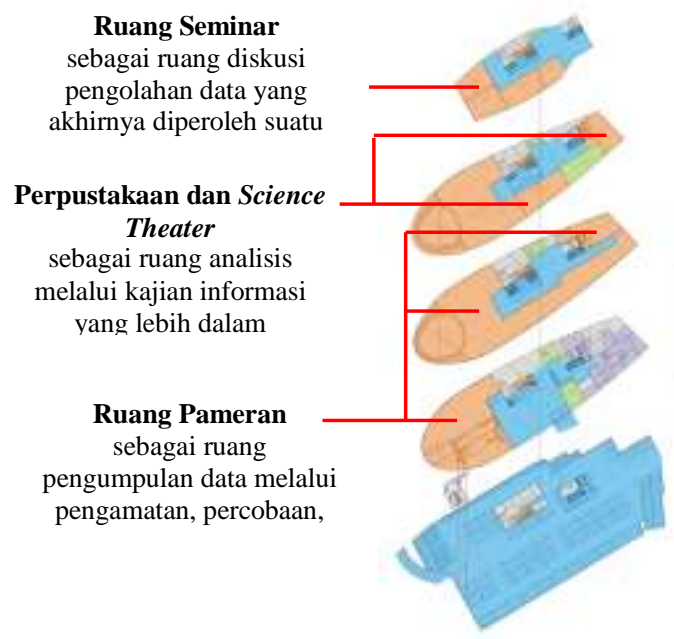

Gambar 9. Penataan Ruang Zona Utama

Pada Gambar 9 dapat terlihat ruang pamer dimetaforakan sebagai ruang pengumpulan data melalui observasi, percobaan dan pengujian. Perpustakaan dan sciene theater sinema dimetaforakan sebagai ruang analisis yang mengolah data lebih dalam. Ruang seminar, untuk diskusi hasil pengolahan data, yang pada akhirnya akan diperoleh suatu hipotesa.

\subsubsection{Analisis Sirkulasi Ruang Pamer}

1. Tujuan : Menentukan sirkulasi pada ruang pamer yang aman dan nyaman

2. Dasar pertimbangan : metafora alur penelitian, keamanan, dan kenyamanan

3. Hasil : sirkulasi pada ruang pamer mengadopsi alur penelitian yang memiliki proses awal (pengamatan) tengah (penelitian) - akhir (hasil), dan fleksibel terhadap kebutuhan peneliti. Sirkulasi ruang pamer memiliki jalan masuk dan keluar yang sama, namun dalam ruangan pengunjung dapat mengunjungi wahana yang diminati terlebih dahulu. Ruang pamer akan direncanakan berupa ruang besar tanpa pembatas tetap, penggunaan panel atau perubahan interior kelompok wahana akan digunakan sebagai pembatas ruang.

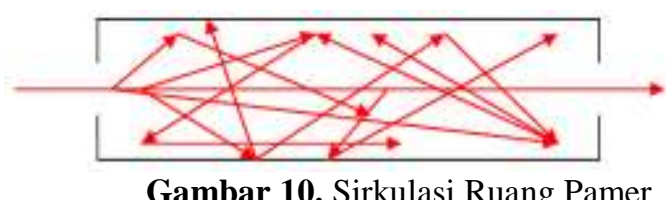

\subsubsection{Analisis Pembentuk Ruang}

1. Tujuan : menentukan pembentuk ruang pada ruang pamer tetap yang sesuai dengan kelompok wahana

2. Dasar pertimbangan : metafora yang disesuaikan dengan tema kelompok wahana, besaran ruang, dan koleksi alat peraga

3. Hasil : mengadopsi sifat IPTEK yang terus berproses, luasan maupun batas dapat berpindah dan konsep pembentuk ruang pada ruang pamer dapat dilihat dalam Tabel 2 (terlampir) dan penataan 
kelompok wahana pada Lampiran 2 (terlampir).

\subsection{Analisa Struktur}

1. Tujuan: menentukan sistem struktur yang sesuai pembebanan

2. Dasar pertimbangan: karakter bangunan, kekuatan dalam menahan beban, keamanan, bentuk dan dimensi vertikal bangunan

3. Hasil :

\section{Sub Structure}

Pondasi bangunan menggunakan tiang pancang karena beban yang ditahan cukup besar dan bangunan memiliki ketinggian empat lantai. Pada tiap titik diberikan dua tiang pancang dan pada core bangunan (sirkulasi vertikal) diberikan lebih banyak pada Gambar 11 dan lihat Lampiran 3.

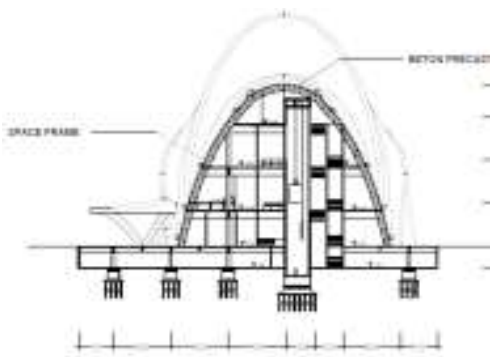

Gambar 11. Potongan Struktur

\section{Supper Structure}

Struktur badan bangunan yang berfungsi menahan beban tiap lantai bangunan dan beban yang bekerja pada bangunan akibat kegiatan di dalamnya. Struktur rangka berupa rigid frame (balok dan kolom) merupakan penyelesaian yang sesuai untuk bangunan yang memiliki ketinggian empat lantai, satu basement, dan satu mezanin. Balok basement menggunakan transfer beam (Gambar 12) karena letak beberapa kolom basement berbeda dari letak kolom lantai dasar. Struktur penahan ramp menggunakan struktur kabel yang dihubungan ke rangka baja kaca bangunan (Gambar 13).

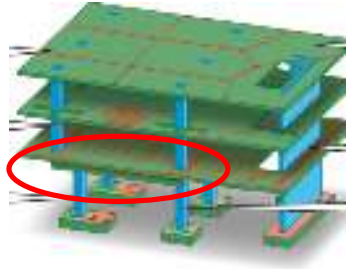

Gambar 12. Contoh Penggunaan Transfer Beam

Sumber : adaptsoft.com

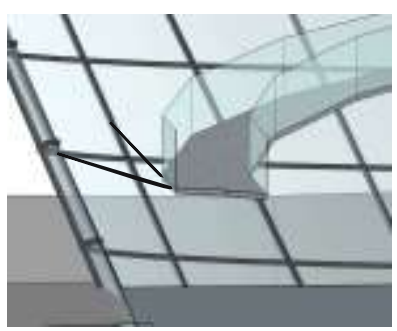

Gambar 13. Struktur Kabel pada Ramp

\section{Upper Structure}

Struktur space frame dipilih dengan pertimbangan bentuk bangunan yang melengkung dan dapat diekspos untuk estetika interior bangunan. Space frame berfungsi sebagai pembentuk selubung bangunan (Gambar 14), sehingga beban yang ditanggung hanyalah beban selubung bangunan bukan beban kegiatan di dalam bangunan. Sambungan antar space frame menggunakan ball joint karena penggunaannya yang fleksibel. Penggunaan material beton precast dengan pengerjaan in-situ digunakan karena molding tiap sisi bangunan berbeda tergantung dari derajat kelengungannya. Kaca bangunan menggunakan laminated glass sebagai penahan masuknya panas matahari dan memiliki keamanan tinggi.

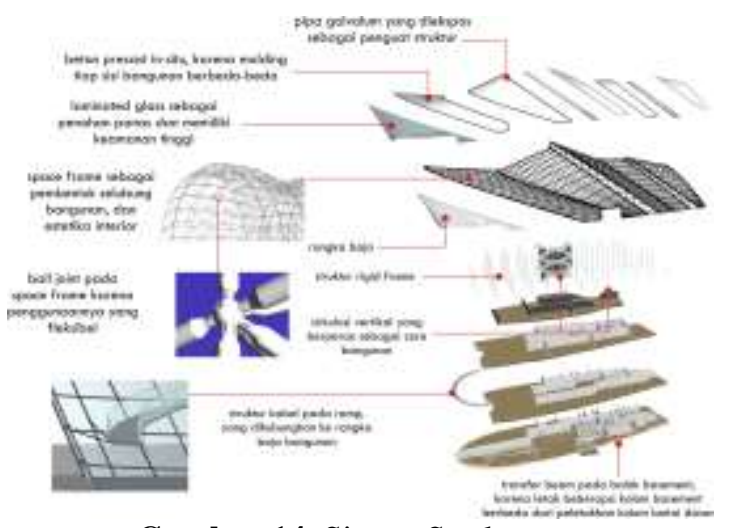

Gambar 14. Sistem Struktur yang Digunakan 


\section{KESIMPULAN (KONSEP DESAIN)}

Konsep rancangan Pusat Ilmu Pengetahuan mengacu pada konsep arsitektur metafora, terutama pada sirkulasi, tata ruang, dan bentuk bangunan. Pusat Ilmu Pengetahuan dirancang untuk mewadahi kegiatan rekreasi dan edukasi bertema IPTEK yang ditujukan untuk masyarakat umum. Penerapan arsitektur metafora juga mempertimbangkan kebutuhan dan kenyamanan pengunjung. Logika struktur bangunan menjadi penting karena konsekuensi dari bentuk bangunan.

Dari hasil analisa serta hasil korelasi dari beberapa data di atas, maka diperoleh hasil berupa rancangan Pusat Ilmu Pengetahuan di Surakarta sebagai berikut.

Nama Objek : Pusat Ilmu Pengetahuan

Lokasi : Jl. Ki Hajar Dewantara

Luas Lahan $\quad: 6.855 \mathrm{~m}^{2}$

Luas Bangunan : $10.454 \mathrm{~m}^{2}$

Daya Tampung : 1.300 orang

Kegiatan : Rekreasi dan edukasi IPTEK melalui koleksi alat peraga

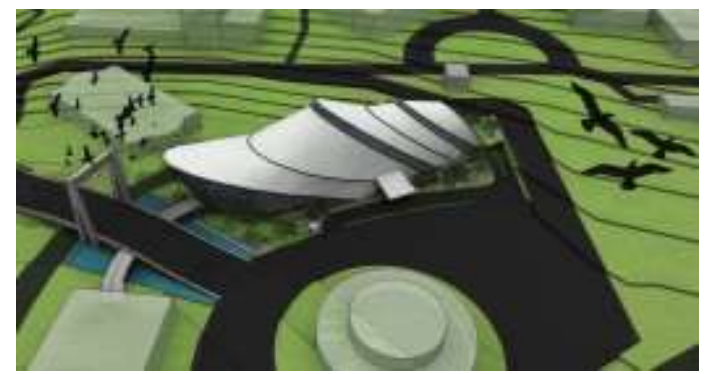

Gambar 15. Perspektif Eksterior

Gambar 15 merupakan eksterior bangunan dari mata burung (atas) yang menunjukkan bentuk bangunan secara keseluruhan.

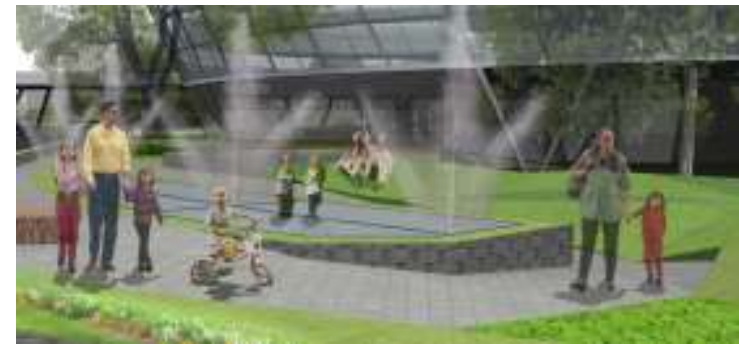

Gambar 16. Outdoor Exhibition

Gambar 16 memperlihatkan area landscape yang dijadikan sebagai outdoor exhibition dan
Gambar 17 memperlihatkan pengolahan landscape yang mengadopsi metafora dinamis yang tak beraturan menciptakan ruang di ruang luar.

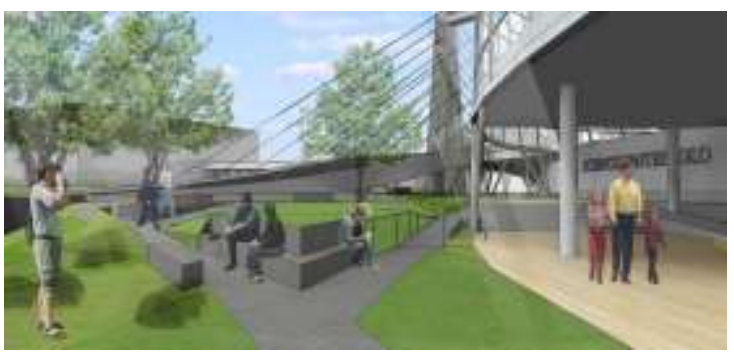

Gambar 17. Perspektif Landscape

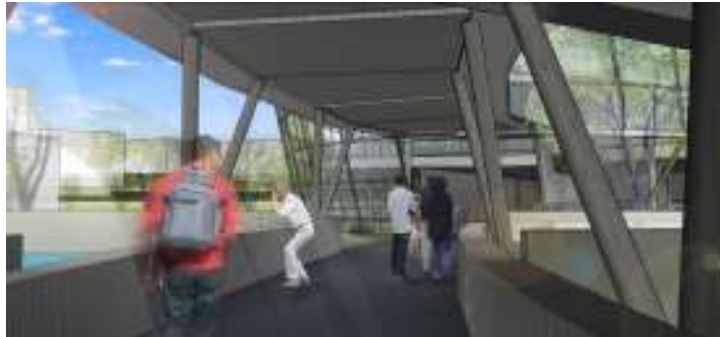

Gambar 18. Jembatan Integrasi

Gambar 18 merupakan jembatan integrasi yang menghubungkan Pusat Ilmu Pengetahuan dengan Solo Trade Center yang melewati bawah jembatan kawasan, agar pengunjung merasa aman saat berpindah tempat.

\section{REFERENSI}

Panda, Jayanarayan \& Bikash R.M, 2010, Adding Fizz to Science.

Peraturan Daerah Kota Surakarta no.10, tahun 2001

Persson, Professong Per-Edvin, 2014, Science center Enhance Learnig, Local Prosperity and Community Development.

Rahm, Jrene, 2004, Multiple Modes of Meaning-Making in a Science Center. 


\section{LAMPIRAN}

Lampiran 1. Pembentuk Ruang Pameran Tetap

\begin{tabular}{|c|c|c|}
\hline NO & JENIS WAHANA & ELEMEN PEMBENTUK RUANG \\
\hline 1 & Wahana Antariksa & $\begin{array}{l}\text { - Antariksa identik dengan suasana luar angkasa yang } \\
\text { penuh dengan misteri, gelap, dan cahaya bintang. } \\
\text { - Pada bagian ini akan lebih memberikan suasana gelap } \\
\text { dengan meminimkan pencahayaan. Pada bagian } \\
\text { langit-langit akan dibiarkan gelap dengan lampu LED } \\
\text { yang tersebar seperti bintang. Sehingga cahaya akan } \\
\text { menerangi pada panel dan koleksi peraga saja. }\end{array}$ \\
\hline 2 & Wahana Optik & $\begin{array}{l}\text { - Optik identik dengan indera penglihatan manusia, } \\
\text { sehingga suasana yang akan ditampilkan adalah } \\
\text { adanya permainan optik, seperti benda peraga atau } \\
\text { ornamen besar dan kecil. }\end{array}$ \\
\hline 3 & Wahana Suara & $\begin{array}{l}\text { - Suara identik dengan dinamis karena suara selalu } \\
\text { menghasilkan volume yang naik-turun (keras- } \\
\text { lembut). } \\
\text { - Panel-panel sebagai pembentuk ruang yang tidak } \\
\text { tetap akan mempunyai ketinggian yang beragam, } \\
\text { yang diadopsi dari grafik suara (naik-turun). }\end{array}$ \\
\hline 4 & Wahana Lingkungan & $\begin{array}{l}\text { - Lingkungan identik dengan elemen pohon dan warna- } \\
\text { warna alam (coklat,hijau, biru, kuning, orange). } \\
\text { Pengadaan pohon besar di dalam wahan dan warna } \\
\text { rumput pada lantai akan memunculkan kesan } \\
\text { lingkungan. Pengadaan koleksi daur ulang dan } \\
\text { warna-warna alam akan lebih memunculkan kesan } \\
\text { alam pada ruang }\end{array}$ \\
\hline 5 & Wahana Tubuhku & $\begin{array}{l}\text { - Pada bagian ini suasana yang akan ditampilkan } \\
\text { adalah panel-panel pembatas dengan bentuk rangka } \\
\text { manusia (tengkorak). Bentuk rangka yang digunakan } \\
\text { adalah tulang rusuk manusia yang dapat dijadikan } \\
\text { sebagai lorong sekaligus pembentuk sirkulasi. }\end{array}$ \\
\hline 6 & Wahana Transportasi & $\begin{array}{l}\text { - Transportasi secara umum menggunakan simbol yang } \\
\text { sering dijumpai di jalan raya. Seperti lampu lalu } \\
\text { lintas, rambu-rambu di jalan raya, hanggar di } \\
\text { bandara, jangkar, dan mercusuar yang serng ditemui } \\
\text { di dermaga. }\end{array}$ \\
\hline 7 & $\begin{array}{l}\text { Wahana } \\
\text { Sosial }\end{array}$ & $\begin{array}{l}\text { - Bagian ini akan menampilkan audiovisual berbentuk } \\
\text { buku yang akan menjelaskan berbagai macam } \\
\text { perasaan yang kita rasakan. Buku besar ini juga } \\
\text { berfungsi sebagai pembentuk ruang. Bentuk buku ini } \\
\text { menggambarkan bahwa interaksi sosial juga } \\
\text { merupakan sebuah ilmu (teori) yang dapat dipelajari } \\
\text { juga. Antara ruang buku-buku besar tersebut } \\
\text { diletakkan alat-alat peraga. } \\
\text { - Plafon akan diturunkan untuk lebih memunculkan } \\
\text { suasana membaca dalam suatu ruang belajar. } \\
\text { - Pencahayaan akan diterangkan sesuai kebutuhan, } \\
\text { yang mengambil dari sifat lampu belajar atau lampu }\end{array}$ \\
\hline
\end{tabular}




\begin{tabular}{|c|c|c|}
\hline & & $\begin{array}{l}\text { baca yang menyala saat adanya kegiatan belajar atau } \\
\text { membaca. }\end{array}$ \\
\hline 8 & Wahana Matematika & $\begin{array}{l}\text { - Pembentuk ruang berupa panel dengan ketinggian } \\
\text { panel yang dimainkan. Permainan ketinggian panel } \\
\text { ini menggunakan perhitungan kelipatan. Walaupun } \\
\text { tinggi panel tidak teratur namun akan tetap teratur } \\
\text { dengan adanya kesamaan perbedaan ketinggian. }\end{array}$ \\
\hline 9 & Wahana Berpikir & $\begin{array}{l}\text { - Pada workshop bagian lantai akan ditinggikan untuk } \\
\text { menciptakan perbedaan ruang dan fungsi kegiatan. } \\
\text { Konsep yang akan digunakan akan menampilkan } \\
\text { rumah, di mana rumah adalah tempat yang paling } \\
\text { nyaman untuk berpikir dan melakukan berbagai } \\
\text { kegiatan. } \\
\text { - Lantai pada bagian workshop akan menggunakan } \\
\text { parket kayu, lalu langit-langit akan dibiarkan terbuka } \\
\text { tanpa plafon. Meja, kursi, lemari, dan lampu kerja } \\
\text { akan digunakan pada laboratorium ini untuk } \\
\text { menampilkan kesan rumah dan kebutuhan dalam } \\
\text { kerja detail. }\end{array}$ \\
\hline 10 & Wahana Robotik & $\begin{array}{l}\text { - Wahana robotik akan menyajikan tempat untuk } \\
\text { pameran peragaan robot, dengan menggunakan warna } \\
\text { putih, abu-abu, dan biru yang memberikan kesan } \\
\text { kecerdasan, dan teknologi tinggi. } \\
\text { - Laboratorium robot akan dibuat dengan kesan } \\
\text { laboratorium itu sendiri. Penggunaan meja, kursi, } \\
\text { lemari, dan meja lampu akan didominasi warna putih } \\
\text { dan biru. Lantai tetap menggunakan parket kayu, } \\
\text { untuk mengurangi kesan dingin dari putih dan biru. } \\
\text { Ketinggian lantai juga akan dinaikkan yang sekaligus } \\
\text { sebagai pembatas ruang. }\end{array}$ \\
\hline 11 & Kids Field & $\begin{array}{l}\text { - Pada wahana kids field berupa ruangan dengan } \\
\text { dinding, lantai, dan plafon sebagai pembatas ruangan. } \\
\text { - Penggunaan warna menggunakan warna kontras. } \\
\text { Karena anak-anak pada usia dini hingga balita lebih } \\
\text { dapat mengenal warna-warna cerah. Dan dari warna } \\
\text { tersebut akan membuat psikologis anak lebih aktif } \\
\text { dan berani untuk beraktivitas. }\end{array}$ \\
\hline
\end{tabular}




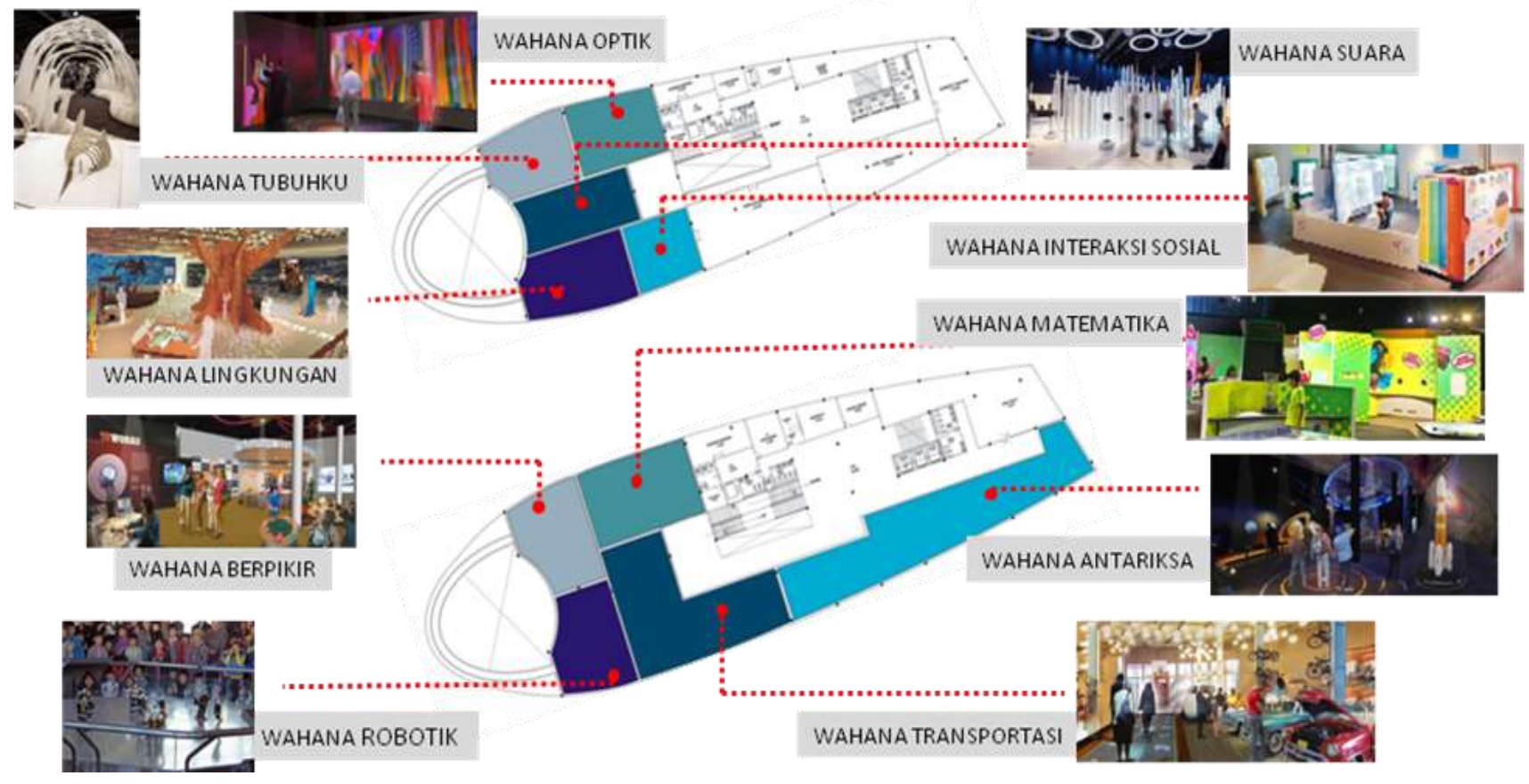

Lampiran 2. Penataan Kelompok Wahana pada Ruang Pameran Tetap

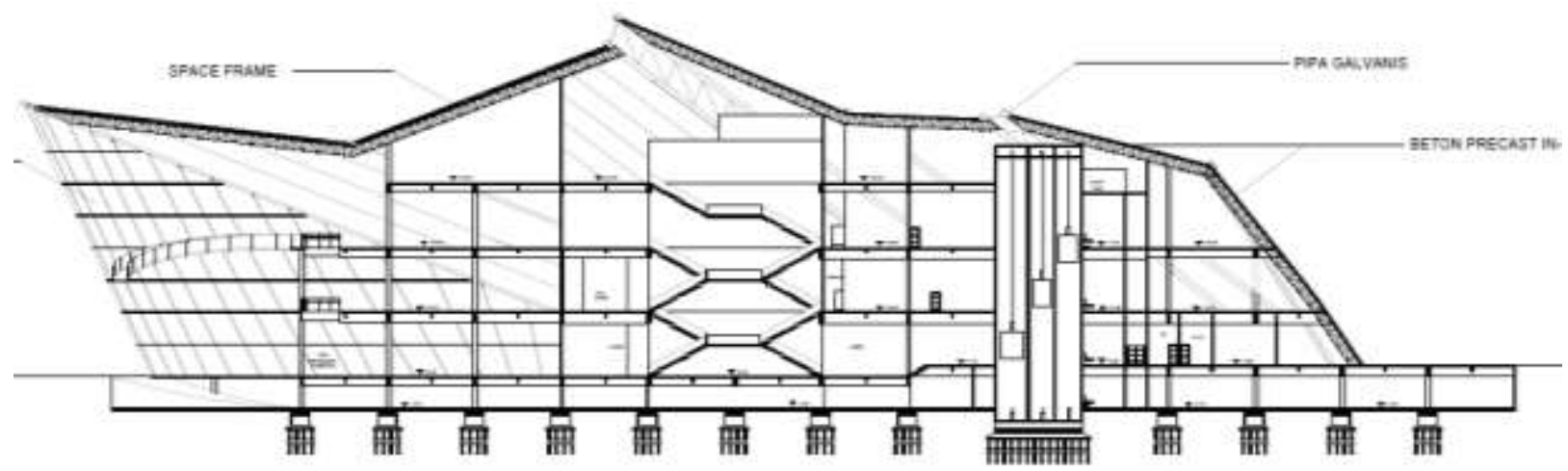

Lampiran 3. Potongan Struktur Bangunan 